\title{
PENGUATAN KEDAULATAN PANGAN DAN PENDAPATAN MASYARAKAT DI ERA NEW NORMAL MELALUI AGRIPRENEURSHIP
}

\author{
Dyah Panuntun Utami1), Istiko Agus Wicaksono1), Didik Widiyantono'), Uswatun Hasanah'1), \\ Isna Windani ${ }^{1)}$, Arta Kusumaningrum ${ }^{1)}$
}

1)Program Studi Agribisnis, Fakultas Pertanian, Universitas Muhammadiyah Purworejo, Jawa Tengah, Indonesia

Corresponding author: Dyah Panuntun Utami

email: dyahpanuntunutami@gmail.com

Diterima 11 Juni 2021, Direvisi 10 Agustus 2021, Disetujui 10 Agustus 2021

\begin{abstract}
ABSTRAK
Pertanian merupakan sektor yang memiliki potensi untuk dikembangkan karena sebagai penyangga kedaulatan pangan. Oleh karena itu perlu perubahan paradigma baru dalam pembangunan pertanian. Pengelolaan pertanian tidak melalui pendekatan usahatani tetapi berorientasi bisnis. Generasi muda yang familiar dengan teknologi digital merupakan harapan dalam regenerasi petani tua. Untuk mendukung terwujudnya ketahanan pangan maka petani muda yang dikenal dengan petani milenial perlu diberikan edukasi tentang agripreneurship. Metode pengabdian masyarakat yang dilakukan adalah penyuluhan yang dimulai dengan pemaparan materi dan dilanjutkan diskusi. Kelompok sasaran pengabdian masyarakat adalah petani milenial desa Wonotulus yang tergabung dalam Karang Taruna. Jumlah peserta sebanyak 20 orang. Penyuluhan dilakukan secara daring menggunakan zoom meeting. Hasil pengabdian masyarakat menunjukkan bahwa peserta sangat antusias terkait dengan materi agripreneurship dan meminta jika penyuluhan tidak hanya teori tetapi juga ada kegiatan pendampingan sehingga petani betul-betul mengerti dan mampu menerapkan pengetahuan tersebut.
\end{abstract}

Kata kunci: petani milenial; agripreneurship; kedaulatan pangan.

\begin{abstract}
Agriculture is a sector that has the potential to be developed as a buffer for food sovereignty. Therefore it is necessaaary to change a new paradigm in agricultural development. Agricultural management is not through a farming approach but is business-oriented. The younger generation who are familiar with digital technology is the hope in regenerating old farmers. To support the realization of food security, young farmers known as millennial farmers need to be given education about agripreneurship. The community service method that is carried out is outreach which starts with the presentation of the material and continues with the discussion. The target group for community service are millennial farmers from Wonotulus village who are members of the Youth Organization. The number of participants was 20 people. Outreach is carried out online using a zoom meeting. The results of community service showed that the participants were very enthusiastic about the agripreneurship material and asked if counseling was not only theoretical but also mentoring activities so that farmers really understood and were able to apply this knowledge
\end{abstract}

Keywords: millennial farmers; agripreneurship; food sovereignty

\section{PENDAHULUAN}

Pertanian merupakan salah sektor yang mempunyai potensi besar untuk dikembangkan karena sebagai penyangga utama kedaulatan pangan. Selain itu produk pertanian juga sebagai pemasok bahan baku sebagian besar industri. Oleh karena itu pembangunan pertanian di masa depan harus berorientasi bisnis.

Paradigma dalam pembangunan pertanian di masa depan tidak lagi melalui pendekatan usahatani melainkan pendekatan agribisnis (Nasruddin et al., 2015). Pembangunan pertanian dengan pendekatan agribisnis perlu perubahan cara berpikir petani dalam mengelola usahatani. Pola berpikir pelaku pertanian tidak lagi pertanian subsisten tetapi pertanian modern. Hal ini dapat dilakukan dengan memberikan edukasi kepada petani tentang agripreneurship.

Agripreneurship mengacu pada kewirausahaan dibidang pertanian (GFRAS, 2021). Rahmawati (2018) dalam Jazilah (2018) menjelaskan agripreneurship merupakan penerapan inovasi kegiatan kewirausahaan dalam industri pertanian.

Pelaku agripreneurship disebut agripreneur yaitu seorang wirausaha yang 
mendukung dan mengelola suatu usaha dalam bidang pertanian (Jazilah, 2018). Berdasarkan pengertian tersebut maka seorang agripreneur harus mampu menciptakan inovasi, mengambil resiko, mengatur perusahaan bisnis, mencari solusi, dan membuat berbagai macam terobosan dalam mengatasi permasalahan bisnisnya.

McElwee (2008) dalam Mukti, Andriani \& Pardian (2018) mengidentifikasi dua jenis petani dilihat dari sisi kewirausahaannya. Pertama, petani sebagai petani. Dalam kelompok ini strategi usaha adalah efisiensi biaya, maksimisasi harga, masih berorientasi produk, dan belum berorientasi pasar. Mereka dalam menjalankan bisnis masih secara individu dan belum dalam kelompok/komunitas. Kedua, petani sebagai entrepreneur. Dalam kelompok ini peluang pasar sudah dieksploitasi, dan sumberdaya pertanian sudah dimanfaatkan secara fleksibel dan inovatif.

Kemampuan mengadopsi teknologi dan melakukan inovasi dalam bisnis pertanian secara cepat dapat dilakukan oleh petani muda atau yang disebut dengan petani milenial. Namun saat ini justru terjadi penurunan minat generasi muda untuk terjun di dunia pertanian. Generasi muda lebih memilih menjalankan usaha diluar sektor pertanian. Kondisi tersebut jika dibiarkan akan berpengaruh pada ketersediaan pangan masyarakat dan kedaulatan pangan. Sementara Nugraha, Hestiawan \& Supyandi (2016) menjelaskan bahwa ketahanan pangan dan swasembada menjadi konsep yang mendominasi kebijakan pangan pemerintah

Berdasarkan data Kementerian Pertanian diketahui bahwa saat ini jumlah petani Indonesia mencapai 33,4 juta orang. Jumlah generasi tua (91\%) dengan usia mendekati 50 tahun hingga 60 tahun. Generasi tua ini kurang dalam penguasaan teknologi. Petani yang termasuk kategori generasi muda hanya sekitar $9 \%$ atau 2,7 juta orang. Generasi muda ini berusia antara 19-39 tahun (Farizi, 2020).

Turunnya jumlah generasi muda menekuni bidang pertanian disebabkan oleh perubahan struktural tenaga kerja, citra buruk sektor pertanian, dan perubahan persepsi generasi muda seiring arus modernisasi. Generasi muda kurang berminat menekuni sektor pertanian karena luas lahan sempit dan kurang menguntungkan secara ekonomi. Selain itu juga terbatasnya akses dukungan layanan pembiayaan (modal) bagi petani muda. Generasi muda semakin tinggi tingkat pendidikan maka semakin selektif memilih pekerjaan (Werembinan et al., 2018) dan (Arvianti et al., 2019).
Menurunnya minat generasi muda menekuni bidang pertanian merupakan suatu keprihatinan. Hal ini mengingat petani milenial merupakan harapan terwujudnya petani sebagai entrepreneur. Pertanian di masa depan semakin mengandalkan petani milenial yang familiar dengan teknologi digital sehingga memperkuat kegiatan produksi dan distribusi. Agripreneur muda menjadi mitra strategis dalam memecahkan kendala pemasaran dan distribusi yang sering dialami petani generasi tua saat ini. Oleh karena itu upaya menarik minat generasi muda terhadap bidang pertanian dapat dilakukan melalui proses pendidikan.

Desa Wonotulus memiliki generasi muda cukup banyak yang tertarik dalam mengembangkan pertanian. Generasi muda ini tergabung dalam Karang Taruna desa Wonotulus. Bidang usaha yang dilakukan petani milenial desa Wonotulus masih didominasi budidaya tanaman hortikultura. Sedangkan budidaya tanaman pangan yaitu padi banyak dilakukan oleh petani berusia tua.

Hasil survei pendahuluan diketahui bahwa petani milenial desa Wonotulus masih lemah dalam penerapan kemampuan kewirausahaan. Pengelolaan pertanian juga cenderung konvensional. Walaupun sebagian besar petani muda menguasai teknologi digital namun dalam kegiatan pemasaran belum memaksimalkan penggunaaan teknologi digital untuk mendukung kegiatan bisnis pertanian yang dijalankan.

Melihat potensi pertanian desa Wonotulus sangat dominan dan sebagai sumber mata pencaharian pokok masyarakat, maka perlu dilakukan transfer ipteks tentang edukasi agripreneurship bagi petani milenial desa Wonotulus.

Tumbuhnya jiwa kewirausahaan dalam diri petani diharapkan dapat meningkatkan kemampuan petani dalam pengelolaan usahatani lebih modern dan berorientasi pasar. Walaupun petani menjalankan bisnis dalam skala kecil, bertujuan untuk memenuhi kebutuhan keluarga, tetapi sebagian juga dijual ke pasar. Petani dalam mengelola usahatani ada yang berusaha sendiri dan ada yang tergabung dalam kelompok tani. Petani juga memiliki mitra dalam kegiatan penjualan. Oleh karena itu petani juga disebut pengusaha. Apabila mereka terorganisir dengan baik maka akan terbentuk sistem bisnis pertanian yang besar.

Berdasarkan uraian tersebut maka tujuan pengabdian masyarakat ini adalah memberikan edukasi tentang agripreneurship kepada petani milenial sehingga dapat memotivasi mereka dalam pengelolaan bisnis pertanian yang 
dijalankan agar lebih menguntungkan. Harapan selanjutnya adalah terjadi regenerasi pelaku pertanian dengan lahirnya wirausaha muda bidang pertanian yang akan mendukung terwujudnya kedaulatan pangan.

\section{METODE}

Pengabdian masyarakat ini menggunakan metode penyuluhan. Penyuluhan dilakukan dengan pemaparan materi dan dilanjutkan dengan diskusi. Metode penyuluhan dipilih pada kegiatan pengabdian masyarakat karena kondisi pandemic covid-19 sehingga Tim tidak bisa bertatap muka secara langsung dengan peserta. Untuk memudahkan komunikasi pada saat kegiatan maka tim mahasiswa yang tempat tinggal di dekat desa Wonotulus berada di lokasi pengabdian. Peserta pengabdian adalah petani milenial yang tergabung dalam Karang Taruna desa Wonotulus. Jumlah peserta 20 orang.

Adapun tahap yang dilakukan adalah:

1. Persiapan Penyuluhan

Tahap persiapan yang dilakukan adalah survei dan koordinasi dengan Ketua Karang Taruna desa Wonotulus terkait permasalahan yang dihadapi dalam pengelolaan pertanian dan pengetahuan tentang agripreneurship. Selanjutnya menyusun tim pengabdian masyarakat dan mengurus perijinan dengan Pemerintah Desa Wonotulus, Karang Taruna, dan Universitas Muhammadiyah Purworejo

2. Pelaksanaan Penyuluhan

Penyuluhan dilakukan secara daring menggunakan zoom meeting dan sebagian peserta mengikuti secara luring. Peserta luring sebanyak 10 orang dan selebihnya daring. Setelah selesai pemaparan materi dilanjutkan dengan diskusi. Materi dishare kepada peserta berupa soft file. Target luaran kegiatan adalah bertambahnya wawasan dan pengetahuan petani milenial tentang agripreneurship.

3. Evaluasi

Evaluasi dilakukan pada akhir kegiatan pengabdian masyarakat. Evaluasi dilakukan dengan menganalisis jalannya penyuluhan dan keaktifan peserta pada saat diskusi. Kegiatan evaluasi ini bertujuan untuk mengetahui apakah transfer ilmu berjalan dengan lancar dan khalayak sasaran dapat menerima dan memahami dengan baik.

Teknik evaluasi yang digunakan adalah observasi (pengamatan) dan tanya jawab langsung kepada peserta.

4. Penyusunan Laporan
Tahap ini adalah tahap penyusunan laporan pengabdian masyarakat sebagai tahap akhir kegiatan.

\section{HASIL DAN PEMBAHASAN}

1. Tahap Koordinasi dan Persiapan Penyuluhan

Pada tahap koordinasi dan persiapan kegiatan, Tim Pengabdian Masyarakat berkoordinasi dengan Pengurus Karang Taruna desa Wonotulus untuk memastikan jadwal kegiatan dan bentuk kegiatan yang dilakukan. Khalayak sasaran yang terdiri dari petani milenial memiliki motivasi tinggi untuk maju dan menambah pengetahuan terkait dalam pengelolaan usaha pertanian. Peserta walaupun termasuk generasi milenial tetapi dalam pengelolaan usaha pertanian belum sepenuhnya memahami ilmu bisnis.

Pada tahap persiapan, Tim Pengabdian Masyarakat melakukan survei pendahuluan dan mencari informasi terkait kebutuhan masyarakat sasaran. Hasil survei pendahuluan diperoleh data bahwa secara umum petani milenial familiar dengan teknologi digital. Semua memiliki HP android dan memanfaatkan media sosial untuk komunikasi. Ada sebagian kecil yang menggunakan media sosial untuk memperlancar bisnis atau usaha. Media sosial digunakan untuk promosi dan penjualan.

Namun masyarakat sasaran masih lemah dalam penggunaan ilmu bisnis dalam pengelolaan usaha dan menjalankan bisnis pertanian. Pengelolaan masih konvensional sehingga keuntungan yang diperioleh belum maksimal. Petani milenial belum memiliki wawasan sebagai agripreneur. Hal ini yang menyebabkan usaha pertanian yang dijalankan kurang berkembang.

Berdasarkan informasi tersebut maka kegiatan pengabdian masyarakat difokuskan pada edukasi agripreneurship pada petani milenial desa Wonotulus sehingga menambah wawasan keilmuan dan bisa merubah mindset atau cara berpikir dalam mengelola bisnis pertanian.

2. Tahap Pelaksanaan Penyuluhan

Berdasarkan hasil survei pendahuluan maka diberikan materi agripreneurship dengan tema "Penguatan Kedaulatan Pangan dan Pendapatan Masyarakat Di Era New Normal Melalui Agripreneurship". Tema ini dipilih dengan mempertimbangkan bahwa di masa pandemi covid-19 telah terjadi perubahan kebiasaan baru dan hal tersebut berdampak pada perubahan perilaku konsumsi dan pembelian konsumen. Petani sebagai produsen harus tanggap terhadap perubahan di era new normal agar bisnis tetap 
menguntungkan. Pengelolaan bisnis tidak lagi mutlak secara konvensional tetapi harus berubah dan menyesuaikan dengan kebiasaan baru. Banyak perusahaan atau bisnis yang terdampak covid-19 dan harus gulung tikar karena tidak mampu menyesuaikan perubahan tersebut.

Berdasarkan tema tersebut maka materi edukasi yang diberikan sebagai berikut: 1. Konsep Agripreneurship dan Agripreneur

2. Peran Agripreneur Milenial dalam Mewujudkan Kedaulatan Pangan

3. Potensi dan Peluang Bisnis Pertanian dari Pekarangan Rumah

4. Peran Teknologi untuk Mendukung Agripreneur Muda di Pedesaan

Tahapan kegiatan dimulai dengan pembukaan, paparan materi oleh narasumber, diskusi dan tanya jawab, dan terakhir penutup. Penyuluhan dilaksanakan secara daring menggunakan zoom meeting dan materi telah dishare kepada masyarakat sasaran melalui WA sehingga semua peserta telah membaca dan mempelajari materi. Tujuannya agar transfer ipteks dapat berjalan lancar dan lebih maksimal. Hal ini juga sebagai antisipasi apabila terjadi gangguan sinyal.

Masyarakat sasaran yang lebih dahulu mempelajari materi diharapkan pada saat diskusi dapat langsung menyampaikan pertanyaan kepada narasumber. Tim mahasiswa yang berada di lokasi pengabdian berperan dalam memandu jalannya kegiatan, diskusi, dan penutupan acara.

Berdasarkan hasil penyuluhan dan diskusi diperoleh data bahwa penggunaan teknologi dalam menjalankan bisnis terutama dalam kegiatan pemasaran masih sangat terbatas. Khalayak sasaran memiliki HP android, mampu menggunakan sosial media seperti WA, facebook dan instagram, namun baru $10 \%$ yang menggunakan teknologi untuk mendukung pengelolaan usaha. Media sosial yang digunakan untuk mempromosikan dan menjual produk baru WA dan facebook. Berdasarkan hal tersebut dapat disimpulkan bahwa petani milenial belum memanfaatkan teknologi digital secara maksimal untuk menjalankan dan mengembangkan bisnis. Masyarakat sasaran juga belum berani mengambil resiko untuk melakukan perluasan pasar menggunakan e-marketplace dan ecommerce lainnya. Masyarakat sasaran juga belum melakukan inovasi dalam hal pengolahan produk. Sebagian besar petani milenial baru menjual produk yang dihasilkan secara lokal di daerah setempat. Padahal sebagai agripreneur dituntut kreatif dan inovatif.

Pekarangan rumah masyarakat cukup luas tetapi belum dimanfaatkan secara optimal sebagai lahan bisnis. Masyarakat masih berfikir bahwa kegiatan pertanian dilakukan di sawah atau areal yang luas di luar pekarangan rumah. Potensi sumber daya lokal yang berlimpah di desa Wonotulus belum dimanfaatkan dan diolah secara maksimal. Masyarakat masih bergantung pada usahatani padi sawah. Pemasaran juga masih tergantung pada pedagang pengepul sehingga harga jual rendah.

Penguasaan ilmu bisnis yang digunakan baru sebatas penetapkan harga jual, penghitungan biaya dan keuntungan. Bagaimana melakukan promosi di media sosial, memperluas daerah pemasaran, menentukan segment pasar dan branding belum dilakukan. Pola pikir masyarakat sangat sederhana yaitu produk laku terjual, tidak rugi dan mampu mencukupi kebutuhan keluarga mereka sudah cukup puas.

Masyarakat sasaran setelah mendengarkan materi yang disampaikan narasumber merasa terbuka wawasan keilmuan dan pengetahuan dalam pengelolaan bisnis. Sektor pertanian merupakan sektor penopang perekonomian masyarakat dan berperan dalam mewujudkan kedaulatan pangan secara nasional. Masyarakat sasaran sangat antusias pada saat diskusi, dan banyak pertanyaan yang diajukan kepada narasumber.

Berikut adalah hasil diskusi dan tanya jawab narasumber dengan masyarakat sasaran.

Tabel 1. Pertanyaan Masyarakat Sasaran kepada Narasumber

\begin{tabular}{|c|c|}
\hline No. & Pertanyaan \\
\hline 1. & $\begin{array}{l}\text { Bagaimanakah memotivasi generasi } \\
\text { muda agar tertarik terjun di dunia } \\
\text { pertanian dan mengembangkan bisnis } \\
\text { pertanian di desa? }\end{array}$ \\
\hline 2. & $\begin{array}{l}\text { Bagaimanakah menumbuhkan jiwa } \\
\text { agripreneurship pada petani muda? }\end{array}$ \\
\hline 3. & $\begin{array}{l}\text { Bagaimanakah mengelola pekarangan } \\
\text { agar menjadi sumber pangan dan } \\
\text { bisnis keluarga? }\end{array}$ \\
\hline 4. & $\begin{array}{l}\text { Apakah ada kegiatan pendampingan } \\
\text { yang dilakukan kampus pada petani } \\
\text { agar petani lebih maju dan semakin } \\
\text { berkembang usahanya? } \\
\text { Jika ada bagaimanakah caranya agar } \\
\text { petani muda desa Wonotulus } \\
\text { mendapatkan pendampingan dari } \\
\text { kampus? }\end{array}$ \\
\hline 5. & $\begin{array}{l}\text { Saran: Sebaiknya kegiatan } \\
\text { penyuluhan tidak hanya satu kali tetapi } \\
\text { beberapa kali dan diberikan praktik } \\
\text { sehingga petani muda desa } \\
\text { Wonotulus benar-benar paham dan } \\
\text { mampu mengelola bisnis dengan baik. }\end{array}$ \\
\hline 6. & Saran: Mohon ada pelatihan \\
\hline
\end{tabular}


penggunaan digital marketing dan ecommerce pada petani muda masyarakat desa Wonotulus sehingga dapat praktik menjual dan mempromosikan produk di $e$ marketplace.

Sumber: Analisis Data Primer (2020)

Berdasarkan Tabel 1 diketahui bahwa masyarakat sasaran sangat antusias dan termotivasi dalam pengelolaan bisnis. Masyarakat memerlukan pendampingan agar transfer ilmu dapat berjalan dengan baik dan masyarakat mampu menjalankan bisnis secara menguntungkan. Masyarakat menyadari potensi alam yang dimiliki, tetapi terbatas dalam penguasaan teknologi. Pembahasan setiap pertanyaan masyarakat sasaran dijelaskan sebagai berikut.

Cara memotivasi generasi muda agar tertarik terjun di dunia pertanian dan mengembangakn bisnis pertanian di desa, dilakukan dengan memberi contoh nyata petani milenial yang sukses mengelola bisnis pertanian. Banyak petani milenial di Indonesia yang sukses. Generasi muda juga harus diberi pengetahuan bahwa bisnis pertanian tidak harus kotor dan berlumpur. Banyak teknologi yang dikembangkan untuk mendukung perkembangan pertanian mulai hulu sampai ke hilir. Sebagai pebisnis tidak harus menanam atau bergelut di sektor budidaya tetapi bisa di sektor pengolahan, pengemasan dan pemasaran. Berdasarkan berita yang bersumber dari wartatani (2020) berikut adalah kisah sukses petani milenial asal Cianjur Jawa Barat yaitu Sandi Octa Susila (26 tahun) yang menggeluti bisnis pertanian dan memproduksi sekitar 141 macam holtikutura. Sandi membina 385 petani dan pengelolaan lahan seluas 120 hektar yang tersebar di berbagai wilayah. Omset yang diperoleh sekitar Rp 500 juta per bulan. Kisah sukses petani milenial yang lain menurut wartaekonomi (2020) adalah Jatu Barmawati (29 tahun). Jatu berasal dari Lampung dan sukses sebagai eksportir manggis di daerah Eropa. Ayobandung (2020) juga meliput Wisnu Saepudin (26 tahun) petani milenial asal desa Pasirlangu, Cisarua, Bandung Barat. Wisnu Saepudin sukses sebagai petani paprika di usia muda.

Cara menumbuhkan

jiwa agripreneurship pada petani muda dapat dilakukan dengan memotivasi dan memberikan pemahaman bahwa petani bukan sebagai pekerjaan tetapi sebagai aktivitas kewirausahaan. Konsep petani sebagai agripreneur, maka petani tidak hanya menjadi buruh tani, tetapi sebagai pemilik usahatani. Petani sebagai agripreneur yang berusia muda maupun tua tidak hanya berkutat pada aspek hulu (produksi), namun juga harus menguasai aspek hilir (pengolahan) sebagai sebuah sistem agribisnis. Perubahan pola pikir atau mindset ini memerlukan proses dan motivasi yang kuat dari dalam diri petani sendiri.

Hasil penelitian Nugroho, Waluyati \& Jamhari (2018) menunjukkan bahwa generasi muda tertarik terjun di dunia pertanian karena faktor finansial, warisan orang tua dan insentif pemerintah. Oleh karena itu perlu peningkatkan peran pemuda dalam kelembagaan pertanian, pengenalan pertanian melalui pendidikan usia dini, peningkatan kualitas pelaku pertanian, mengembangkan pertanian terpadu, penguatan cooperative farming, serta asuransi pertanian dan jaminan pemasaran.

Hal ini juga sesuai dengan Herawaty (2016) yang menyatakan bahwa untuk mendorong program peningkatan kewirausahaa maka pemerintah harus melihat faktor eksternal dan internal generasi muda. Faktor eksternal antara lain motivasi dari pihak lain, fasilitas mendirikan usaha, regulasi yang jelas dan tidak diskriminatif, serta suasana yang kondusif untuk mengembangkan kewirausahaan. Sedangkan faktor internal berasal dari dalam diri pengusaha itu sendiri berkaitan dengan motivasi untuk berwirausaha.

Selanjutnya untuk menumbuhkan jiwa kewirausahaan pada generasi muda dapat dilakukan dengan edukasi, memberikan motivasi, dan perlu adanya kebijakan pemerintah untuk memberikan fasiltas yang mendukung bisnis pertanian. Pemberian motivasi dimulai dengan menumbuhkan kesadaran dari diri petani itu sendiri. Pengabdian masyarakat Yuliani, Novita \& Pramestari (2019) kepada siswa SMA Muhammadiyah I Jakarta dilakukan dengan pendekatan inside out, yaitu mengawali sesuatu (termasuk melakukan perubahan) dari diri sendiri, bukannya pihak luar. Pendekatan ini sangat baik dalam mengembangkan pribadi para siswa untuk menjadi wirausaha mandiri dimasa yang akan datang. Jadi menumbuhkan kesadaran untuk menjadi wirausaha harus berasal dari dalam diri sendiri. Dengan pendekatan inside out maka siswa sejak dini telah memiliki motivasi dan semangat berwirausaha, sehingga tidak mudah menyerah dalam mengelola bisnis di masa depan.

Pemuda pada dasarnya memiliki persepsi ekonomi yang positif terhadap sektor pertanian (Addo, 2018 dan Magagula \& Tsvakirai, 2020). Magagula \& Tsvakirai (2020) lebih lanjut menjelaskan adanya penyediaan pendidikan pertanian sekolah menengah, dukungan dana yang besar sehingga persepsi pemuda untuk berpartisipasi dalam 
kewirausahaan positif.

Selain itu, minat agripreneur muda dipengaruhi juga oleh tingkat pendidikan nonformal, motivasi, dukungan masyarakat, dukungan sumber informasi, dan kemampuan wirausaha (Harniati \& Anwarudin, 2018 dan Oktavia \& Suprapti, 2020).

Bahkan jiwa kewirausahaan dapat dipupuk sejak dini dengan adanya peran orang tua dalam memberikan pengarahan. Penelitian Nurlaela et al. (2020) menunjukkan bahwa peran orang tua memberikan pengaruh positif dalam pembentukan perilaku wirausaha. Peran orang tua ini antara lain pemberian fasilitas dan motivasi. Selain itu adanya pewarisan usahatani kepada anak juga berdampak pada pemilihan profesi sebagai petani.

Berdasarkan uraian tersebut dapat disimpulkan bahwa menumbuhkan jiwa kewirausahaan pada generasi muda memerlukan peran banyak pihak, seperti keluarga, lembaga pendidikan, dan pemerintah. Selain itu juga perlu kebijakan pemerintah yang mendorong generasi muda menekuni bisnis pertanian.

Cara pengelolaan pekarangan agar menjadi sumber pangan dan bisnis keluarga dapat dilakukan dengan optimalisasi lahan pekarangan. Alasan pekarangan harus dimanfaatkan karena pekarangan memiliki potensi sebagai sumber bahan pangan di sekitar rumah (Ashari et al., 2012). Banyak teknologi budidaya tanaman untuk lahan sempit dengan produktivitas tinggi. Teknologi optimalisasi lahan pekarangan dapat menggunakan teknik vertikultur (budaya tanaman secara vertikal), hidroponik, dan yang sedang trend saat ini adalah budikdamber (budaya ikan dalam ember). Pengabdian masyarakat yang dilakukan oleh Subandar, Nurba \& Gafur (2015), Nurmawati \& Kadarwati (2016), (Diwanti, 2018), (Hidayati, Rosawanti, Arfianto \& Hanafi, 2018), (Sarjiyah \& Kamardiani, 2019), (Sukenti, Sukiman, Suripto, Rohyani \& Jupri, 2019), (Sarjiyah \& Istiyanti, 2020) dan (Ekawati, Saputri, Kusumawati, Paonganan \& Ingesti, 2021) menunjukkan bahwa dengan pemanfaatan lahan pekarangan untuk budidaya sayuran secara vertikultur, hidroponik, dan pot atau polybag maka masyarakat mendapatkan sayuran sehat dan aman dari pekarangan, serta lingkungan lebih asri.

Budidaya sayuran secara vertikal (vertikultur) meningkatkan produktivitas lahan. Hal ini disebabkan teknik penanaman disusun ke atas. Sebagai contoh, vertikultur menggunakan paralon maka diperoleh beberapa lubang tanam. Sementara jika ditanam secara konvensional di lahan memerlukan lahan cukup luas. Teknik budidaya vertikultur dapat menggunakan media tanah atau menggunakan media air (hidroponik).

Lahan pekarangan yang sempit juga dapat dilakukan optimalisasi lahan pekarangan dengan membudidayakan ikan dan sayuran secara bersamaan. Teknologi ini dikenal dengan budikdamber. Budikdamber adalah budidaya tanaman dan ikan didalam ember secara bersamaan. Budikdamber ditemukan oleh Juli Nursandi, S.Pi., M.Si. dosen Budidaya Perikanan Politeknik Negeri Lampung. Petani agar mendapatkan keuntungan secara finansial maka juga menanam sayuran di sekitar budikdamber. Budikdamber berpotensi sebagai sumber penghasilan tergantung pada jumlah budikdamber yang digunakan (Vebriansyah, 2020).

Pertanyaan terkait cara mendapatkan pendampingan dari kampus dapat dilakukan dengan mengirimkan surat permohonan ke kampus ditujukan kepada Dekan Fakultas Pertanian Universitas Muhammadiyah Purworejo. Selanjutnya surat permohonan tersebut akan didisposisi kepada Ketua Program Studi Agribisnis terkait permintaan pendampingan dan pelatihan. Program studi selanjutnya membentuk tim pengabdian dan memproses kegiatan pengabdian masyarakat ke Lembaga Penelitian dan Pengabdian Masyarakat Universitas Muhammadiyah Purworejo (LPPM). Desa Wonotulus juga dapat diproses dan diajukan sebagai desa binaan Fakultas Pertanian Universitas Muhammadiyah Purworejo. Hal ini perlu dilakukan karena perguruan tinggi memiliki peran penting dalam melahirkan wirausaha di lingkungan kampus maupun masyarakat.

Hal ini seperti pengabdian masyarakat yang dilakukan Poltak et al. (2021) kepada wirausaha pemula bidang kelautan dan perikanan di Politeknik Kelautan dan Perikanan Sorong bahwa perguruan tinggi memiliki peran dalam membentuk sosok wirausaha yang handal dan terampil. Kegiatan pendampingan dengan metode CPDT dan coaching dapat menumbuhkan kreativitas kelompok wirausaha, mahasiswa mampu menyusun proposal sesuai panduan, dan mampu melakukan presentasi yang efektif.

Besarnya antusias dan semangat petani muda desa Wonotulus dalam mengikuti penyuluhan telah memotivasi masyarakat sasaran meminta pendampingan dari kampus. Tujuan pendampingan agar jiwa agripreneur betul-betul tertanam di dalam diri petani dan muncul agripreneur muda di desa Wonotulus. Harapan selanjutnya adalah petani memiliki kemampuan yang baik dalam menjalankan bisnis pertanian agar lebih menguntungkan. 
Petani juga mampu menekan resiko dan mengambil keputusan yang tepat dalam bisnis. Berkaitan dengan perkembangan teknologi, masyarakat sasaran juga meminta diberikan pelatihan penggunaan digital marketing dan ecommerce dalam bisnis pertanian. Hal ini disebabkan petani muda desa Wonotulus baru menggunakan WA dan facebook untuk mendukung kegiatan bisnis.

Berikut adalah dokumentasi kegiatan penyuluhan pada peserta secara luring dan daring.
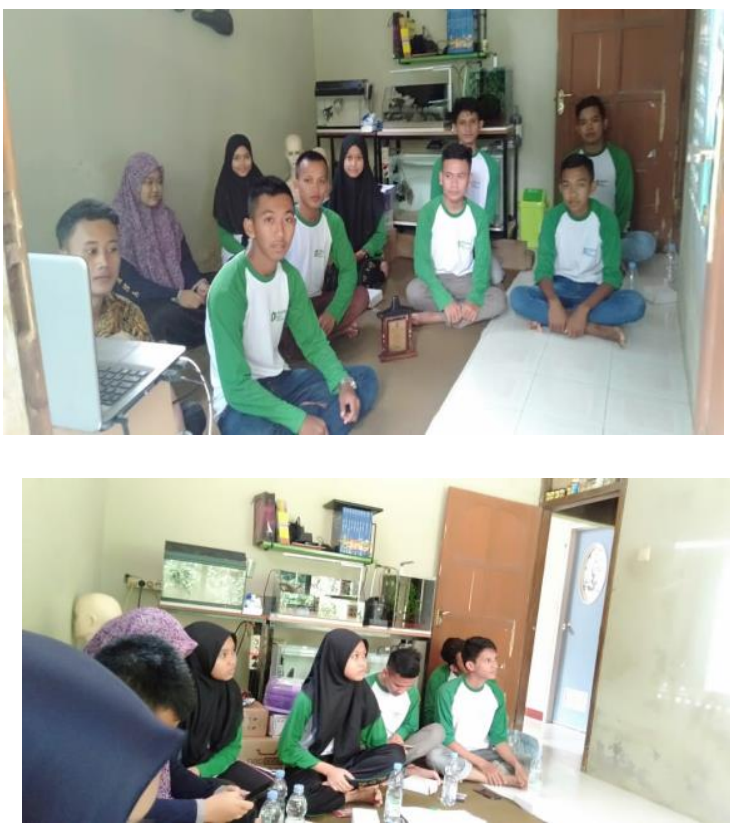

Gambar 1. Khalayak Sasaran Yang Mengikuti Kegiatan Penyuluhan Secara Luring

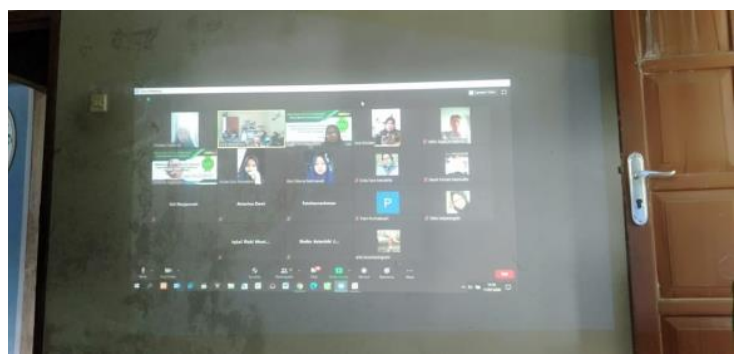

Gambar 2. Khalayak Sasaran Yang Mengikuti Kegiatan Penyuluhan Secara Daring

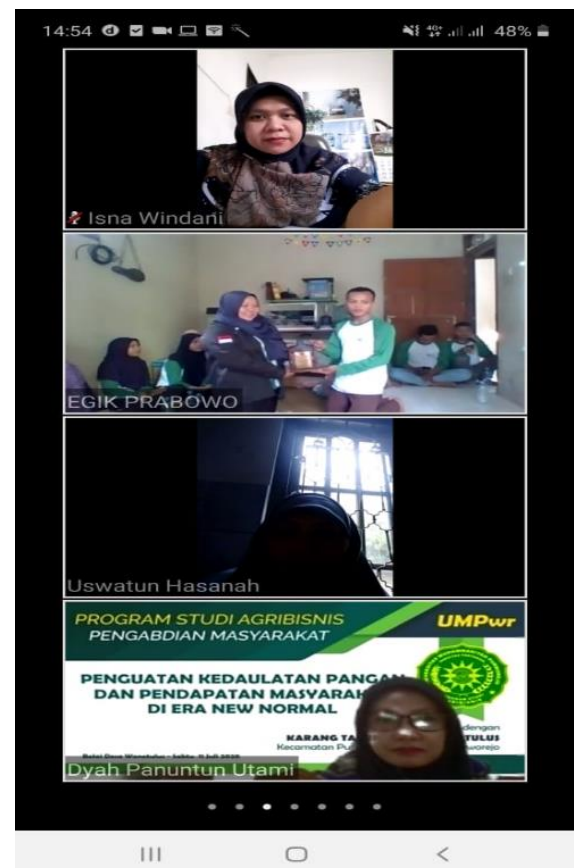

Gambar 3. Penutupan dan Penyerahan Kenang-Kenangan Kepada Khalayak Sasaran

\section{Tahap Evaluasi}

Tahap evaluasi dilakukan untuk mengetahui tingkat keberhasilan transfer ipteks dari tim pengabdian masyarakat kepada masyarakat sasaran. Evaluasi dilakukan dengan mengamati jalannya diskusi dan antusias masyarakat sasaran terhadap materi yang diberikan. Antusias masyarakat sasaran sangat tinggi terlihat dari banyaknya pertanyaan yang diajukan serta rasa ingin tahu yang besar terhadap materi yang diberikan. Bahkan meminta agar diberikan pendampingan dan pelatihan secara berkelanjutan.

4. Tahap Penyusunan Laporan

Tahap ini merupakan tahap akhir dari kegiatan pengabdian masyarakat. Pelaporan kegiatan adalah bentuk pertanggungjawaban Tim Pengabdian Masyarakat Program Studi Agribisnis kepada Lembaga Penelitian dan Pengabdian Masyarakat Universitas Muhammadiyah Purworejo yang telah memberikan fasilitas dan hibah pendanaan.

\section{SIMPULAN DAN SARAN}

Berdasarkan hasil kegiatan pengabdian masyarakat tentang edukasi agripreneurship pada petani milenial desa Wonotulus dapat disimpulkan bahwa masyarakat sasaran sangat antusias dan termotivasi untuk menerapkan ilmu bisnis dalam pengelolaan usaha dibidang pertanian. Untuk meningkatkan kemampuan dan ketrampilan petani dalam pengelolaan bisnis pertanian perlu dilakukan pendampingan dan pelatihan sehingga petani berusia muda 
maupun tua benar-benar mampu menerapkan ilmu bisnis dalam mengelola usaha.

Saran untuk keberlanjutan usaha petani adalah perlu dilakukan pendampingan, pelatihan dan transfer ipteks yang terstruktur. Desa Wonotulus agar semakin berkembang dan muncul agripreneur muda dapat dijadikan desa binaan Universitas Muhammadiyah Purworejo. Pendampingan agar efektif sebaiknya melibatkan narasumber dari berbagai disiplin ilmu. Masyarakat desa Wonotulus apabila memerlukan transfer ipteks dapat berkonsultasi ke kampus.

\section{UCAPAN TERIMAKASIH}

Tim Pengabdian Masyarakat Program Studi Agribisnis mengucapkan banyak terima kasih kepada Lembaga Penelitian dan Pengabdian Masyarakat (LPPM) Universitas Muhammadiyah Purworejo yang telah memberikan hibah pendanaan dalam pelaksanaan kegiatan ini, Karang Taruna Desa Wonotulus yang telah menyediakan fasilitas kegiatan pengabdian masyarakat dan semangat yang tinggi untuk maju, serta semua pihak yang telah membantu terlaksananya kegiatan pengabdian masyarakat. Semoga kegiatan pengabdian ini memberikan manfaat kepada masyarakat.

\section{DAFTAR RUJUKAN}

Addo, L. K. (2018). Factors Influencing Agripreneurship and Their Role in Agripreneurship Performance Among Young Graduate Agripreneurs. International Journal of Environment, Agriculture and Biotechnology, 3(6), 2051-2066. Diakses dari https://doi.org/10.22161/ijeab/3.6.14

Arvianti, E. Y., Masyhuri, M., Waluyati, L. R., \& Darwanto, D. H. (2019). Gambaran Krisis Petani Muda Indonesia. Agriekonomika, 8(2), 168-180. Diakses dari https://doi.org/10.21107/agriekonomika.v $8 \mathrm{i} 2.5429$

Ashari, Saptana, \& Purwantini, T. B. (2012). Potensi dan Prospek Pemanfaatan Lahan Pekarangan untuk Mendukung Ketahanan Pangan. Forum Penelitian Agro Ekonomi, 30(1), 13-30. Diakses dari https://doi.org/10.21082/fae.v30n1.2012. 13-30

ayobandung. (2020). Kisah Sukses Petani Milenial Asal Pasirlangu, Sebulan Raup Puluhan Juta. Ayobandung.Com. Diakses dari

https://ayobandung.com/read/2020/03/05 /81635/kisah-sukses-petani-milenial-asalpasirlangu-sebulan-raup-puluhan-juta

Diwanti, P. D. (2018). Pemanfaatan Pertanian
Rumah Tangga (Pekarangan Rumah) Dengan Teknik Budidaya Tanaman Sayuran Secara Vertikultur. Martabe: Jurnal Pengabdian Kepada Masyarakat, 1(3), 101-107. Diakses dari http://jurnal.um-

tapsel.ac.id/index.php/martabe/article/vie w/486/pdf

Ekawati, R., Saputri, L. H., Kusumawati, A., Paonganan, L., \& Ingesti, P. S. V. R. (2021). Optimalisasi Lahan Pekarangan dengan Budidaya Tanaman Sayuran sebagai Salah Satu Alternatif dalam Mencapai Strategi Kemandirian Pangan. PRIMA: Journal of Community Empowering and Services, 5(1), 19-28. Diakses dari https://doi.org/10.20961/prima.v5i1.42397

Farizi, R. Al. (2020). Petani Muda Tergerus, Dominan Petani Tua Tanpa Teknologi. 13 April 2020. Diakses dari https://fajar.co.id/2020/04/13/petanimuda-tergerus-dominan-petani-tuatanpa-teknologi/

GFRAS. (2021). The Role of RAS for Inclusive Agripreneurship Background and Rationale. Joomla Experts. Diakses dari https://www.g-

fras.org/en/agripreneurship.html

Harniati, \& Anwarudin, O. (2018). The Interest and Action of Young Agricultural Entrepreneur on Agribusiness in Cianjur Regency, West Java. Jurnal Penyuluhan, 14(2), 267505. Diakses dari https://doi.org/10.25015/penyuluhan.v14i 1.18913

Herawaty. (2016). Wirausaha Muda dalam Peningkatan Pembangunan Pertanian. Jurnal Agrica Ekstensia, Vol.10(2), Hal 81$87 . \quad$ Diakses dari https://core.ac.uk/download/pdf/3260370 01.pdf

Hidayati, N., Rosawanti, P., Arfianto, F., \& Hanafi, N. (2018). Pemanfaatn Lahan Sempit Untuk Budidaya Sayuran Dengan Sistem Vertikultur (Utilization of narrowland area to cultivate vegetables by verticulture system). PengabdianMu, 3, 40-46. Diakses dari http://journal.umpalangkaraya.ac.id/index .php/pengabdianmu/article/view/28?articl esBySameAuthorPage $=2$

Jazilah, Syakiroh. (2018). Agripreneurship di Era Revolusi Industri 4.0. 150-154. Diakses dari https://proceeding.unikal.ac.id/index.php/j ob/article/view/185

Magagula, B., \& Tsvakirai, C. Z. (2020). Youth Perceptions of Agriculture: Influence of Cognitive Processes on Participation in 
Agripreneurship. Development in Practice, 30(2), 234-243. Diakses dari https://doi.org/10.1080/09614524.2019.1 670138

Mukti, G. W., Andriani, R., \& Pardian, P. (2018). Transformasi Petani Menjadi Entrepreneur (Studi Kasus Pada Program Wirausaha Muda Pertanian Di Fakultas Pertanian Universitas Padjadjaran). AGRICORE, 3(2), 508-524. Diakses dari http://jurnal.unpad.ac.id/agricore/article/vi ew/20491/9546

Nasruddin, W., Junaidi, E., Musyadar, A., \& Dayat, D. (2015). Tingkat Kewirausahaan Berbagai Pelaku Agribisnis di Wilayah Bogor. Jurnal Agribisnis Indonesia, 3(1), 55-66. Diakses dari https://doi.org/10.29244/jai.2015.3.1.5466

Nugraha, A., Hestiawan, M. S., \& Supyandi, D. (2016). Refleksi Paradigma Kedaulatan Pangan Di Indonesia: Studi Kasus Gerakan Pangan Lokal Di Flores Timur. Agricore: Jurnal Agribisnis Dan Sosial Ekonomi Pertanian Unpad, 1(2). Diakses dari

https://doi.org/10.24198/agricore.v1i2.227 17

Nugroho, A. D., Waluyati, L. R., \& Jamhari, J. (2018). Upaya Memikat Generasi Muda Bekerja Pada Sektor Pertanian di Daerah Istimewa Yogyakarta. JPPUMA: Jurnal IImu Pemerintahan Dan Sosial Politik Universitas Medan Area, 6(1), 76-95. Diakses dari https://doi.org/10.31289/jppuma.v6i1.125 2

Nurlaela, Siti., Hariadi, Sunarru Samsi., \& Raya, Alia. Bihrajihat. (2020). Peran Orang Tua dalam Mengembangkan Perilaku Wirausaha Petani Muda Hortikultura di Daerah Istimewa Yogyakarta. Prosiding Seminar Nasional Pembangunan Dan Pendidikan Vokasi Pertanian Politeknik Pembangunan Pertanian Manokwari, November, 223-232. Diakses dari https://jurnal.polbangtanmanokwari.ac.id/i ndex.php/prosiding/article/view/141

Nurmawati, \& Kadarwati, S. (2016). Vertikultur Media Pralon Sebagai Upaya Memenuhi Kemandirian Pangan Di Wilayah Peri Urban Kota Semarang. Jurnal Pendidikan Sains, 04(02), 19-25. Diakses dari https://jurnal.unimus.ac.id/index.php/JPKI MIA/article/view/2158

Oktavia, S. E., \& Suprapti, I. (2020). Motivasi Generasi Muda dalam Melakukan Usahatani Desa Pangkatrejo Kabupaten Lamongan. Agriscience, 1(November), 383-395. Diakses dari https://journal.trunojoyo.ac.id/agriscience/ article/view/8022

Poltak, H., Prakoso, G. H., Gunaisah, E., Ulat, M. A., Mustasim, Latif, M. Z., Sayuti, M., Sururi, M., Muhfizar, \& Winarno, B. (2021). Pendampingan Kelompok Kewirausahaan Muda bagi Pemula Bidang Kelautan dan Perikanan di Politeknik Kelautan dan Perikanan Sorong. Selaparang. Jurnal Pengabdian Masyarakat Berkemajuan, 4(April), 96-103. Diakses dari http://journal.ummat.ac.id/index.php/jpmb /article/view/4025

Sarjiyah \& Kamardiani, Diah Rina. (2019). Optimalisasi Pemanfaatan Pekarangan Perkotaan Dalam Pemenuhan Kebutuhan Sayuran Di Kampung Suronatan. Seminar Nasional ABDIMAS II. Sinergi Dan Strategi Akademisi, Business, Dan Government (ABG) Dalam Mewujudkan Pemberdayaan Masyarakat Yang Berkemajuan Di Era Industri 4.0, 1863$1872 . \quad$ Diakses dari https://prosiding.umy.ac.id/semnasppm/in dex.php/psppm/article/view/534

Sarjiyah \& Istiyanti, Eni. (2020). Optimalisasi Pemanfaatan Lahan Pekarangan Untuk Pemenuhan Kebutuhan Sayuran Yang Sehat Dan Aman. Prosiding Seminar Nasional Program Pengabdian Masyarakat, 381-388. Diakses dari https://doi.org/10.18196/ppm.32.221

Subandar, I., Nurba, D., \& Gafur, A. (2015). Peningkatan Produktivitas Lahan Melalui Pemanfaatan Lahan Perkarangan di Meureubo Kabupaten Aceh Barat. Jurnal Agrotek Lestari, 1(1), 21-26. Diakses dari https://doi.org/10.35308/jal.v1i1.427

Sukenti, K., Sukiman, S., Suripto, S., Rohyani, I. S., \& Jupri, A. (2019). Optimalisasi Pemanfaatan Lahan Pekarangan Sebagai Upaya dalam Membantu Ketersediaan Pangan dan Perekonomian Masyarakat di Desa Sukarema, Kabupaten Lombok Timur. Jurnal Pengabdian Magister Pendidikan IPA, 2(1), 97-101. Diakses dari https://doi.org/10.29303/jpmpi.v2i1.362

Vebriansyah, R. (2020). Laba dari Budikdamber. TRUBUS. Diakses dari https://www.trubus-online.co.id/laba-daribudikdamber/

wartaekonomi. (2020). Kisah Sukses Petani Milenial Jatu Barmawati Jadi Inspirasi di Program YESS. Wartaekonomi.Co.Id. Diakses dari https://www.wartaekonomi.co.id/read317 435/kisah-sukses-petani-milenial-jatubarmawati-jadi-inspirasi-di-program-yess wartatani. (n.d.). Sandi Octa Jadi Petani 
Milenial Sukses, Sebulan Kantongi Rp 500 Juta. Www.Wartatani.Co. Diakses dari

https://www.wartatani.co/3237/headline/s andi-octa-jadi-petani-milenial-suksessebulan-kantongi-rp-500-juta/

Werembinan, C. S., Pakasi, C. B. D., \& Pangemanan, L. R. J. (2018). Persepsi Generasi Muda Terhadap Kegiatan Pertanian Di Kelurahan Buha Kecamatan Mapanget Kota Manado. AgriSosioekonomi, 14(3), 123. Diakses dari https://doi.org/10.35791/agrsosek.14.3.20 18.21542

Yuliani, N., Novita, D., \& Pramestari, D. (2019). Menumbuhkan Jiwa Wirausaha Kawula Muda Di Era Milenial Melalui Pendekatan Inside-Out. Ikraith-Abdimas, 2(2), 12-22. Diakses dari https://media.neliti.com/media/publication s/268416-menumbuhkan-jiwa-wirausahakawula-mudadi-8c70e932.pdf 